\title{
PELATIHAN PENYUSUNAN BAHAN AJAR BAHASA INDONESIA BAGI GURU SMP/MTS DI SURAKARTA
}

\author{
Miftakhul Huda dan Rahmah Purwahida \\ $\overline{\text { Jurusan Pendidikan Bahasa, Sastra Indonesia, dan Daerah }}$ \\ Fakultas Keguruan dan Ilmu Pendidikan \\ Universitas Muhammadiyah Surakarta \\ hyuda_86@yahoo.com
}

\begin{abstract}
This training has several goals, namely to open insights, and observers of Indonesian teachers about gender equality in everyday life, giving insight to analyze the value of inequality/gender equality, and compile teaching materials Indonesian perspective of gender equality. Implementation of this training method is applied in two stages: the preparation stage and implementation stage. Preparation stage includes internal coordination (: preparatory concepts, preparation of materials) and the coordination of external (: contacting a speaker, contact the PDM Surakarta, Surakarta Dikspora contacted, and invited the school). Implementation stage is the stage of core training employed by interactive lectures, questions and answers, and tutorials. Training lasted for one day and 13 participants attended junior secondary school teachers. Based on analysis of implementation of teacher understand the preparation of teaching materials Indonesian gender perspective. This is evident from the responses of the material, examples, and instructional materials containing ilutrasi gender inequality.
\end{abstract}

Kata kunci: pelatihan, bahan ajar, jender

\section{PENDAHULUAN}

\section{Analisis Situasi}

Pendidikan nasional merupakan sarana untuk mencapai cita-cita nasional (Tilaar, 2004: 14). Pendidikan nasional mengupayakan penerus bangsa yang mampu mengemban amanah untuk mewujudkan cita-cita nasional. Dalam rangka membentuk manusia yang utuh, pendidikan di Indonesia dituntut untuk menghasilkan sumberdaya manusia yang menjunjung tinggi hak-hak manusia, di samping bertanggung jawab, berakhlak mulia, dan sadar hukum. Salah satu wujud sikap menjunjung tinggi hak-hak manusia adalah menjunjung tinggi adanya kesetaraan dan keadilan jender.

Piagam Deklarasi Hak Asasi Manusia yang diimplementasikan tahun 1984, dua tahun setelah perang dunia kedua, menekankan kesetaraan jenis kelamin (Engineer, 2003: 3). Hal ini semakin memperkuat bahwa keadilan jender patut menjadi perhatian untuk diimplementasikan di segala bidang kehidupan sebab konsep hak asasi manusia jelas menekankan masalah keadilan jender. 
Permasalahan yang belum tuntas diselesaikan hingga kini pendidikan di Indonesia belum sepenuhnya melaksanakan cita-cita luhur bangsa ini sebagaimana yang diamanatkan dalam UUD 1945. Oleh karena itu, wajar saja bila belum terbentuk sumberdaya manusia yang menjunjung tinggi hakhak manusia, di samping bertanggung jawab, berakhlak mulia, dan sadar hukum. Hal itu terjadi, salah satunya disebabkan bahan ajar di sekolah dan perguruan tinggi di Indonesia yang belum merepresentasikan sikap menjunjung tinggi hak-hak manusia salah satunya dalam menjunjung tinggi adanya kesetaraan dan keadilan jender.

Upaya penyampaian kesetaraan jender sejak dini tidak dilaksanakan secara maksimal sebagaimana program pemerintah, terlihat dari masih banyaknya buku teks Bahasa Indonesia yang menggunakan kutipan karya sastra dan contoh-contoh kalimat yang bias jender (Irawan, 2008: 2). Sejumlah penelitian yang pernah dilakukan beberapa ahli dan lembaga kajian wanita berkaitan dengan persoalan jender dalam buku-buku ajar (Bahasa Indonesia, IPS, Agama, dan PPKN) yang digunakan dari tingkat sekolah dasar sampai sekolah menengah masih menunjukkan adanya bias jender yang demikian kuat mengakar pada buku-buku ajar tersebut.

KTSP memberikan peluang kepada sekolah untuk menyusun kurikulumnya sendiri. KTSP hanya memberikan kompetensi dasar, sedangkan indikator yang harus dicapai siswa berkaitan dengan kompetensi dasar tersebut dibuat oleh guru yang bersangkutan. Dengan demikian, dibutuhkan kompetensi guru untuk menilai potensi siswa dan lingkungannya.

Pelaksanaan KTSP di sekolah harus dibarengi dengan peningkatan kuantitas dan kualitas guru yang selama ini menjadi masalah serius yang dihadapi pendidikan di Indonesia. KTSP memang sejalan dengan dinamika sosial-politik di Indonesia pasca-
Orde Baru. Namun, apakah KTSP dapat dilaksanakan dengan baik di setiap sekolah mengingat kualitas guru yang belum memadai. KTSP memberikan kebebasan untuk menyusun silabus, mencari dan memilih bahan ajar, tetapi wawasan dan pengetahuan guru yang sangat terbatas.

Standardisasi penulisan bahan ajar meliputi empat aspek, yaitu materi, penyajian, bahasa/keterbacaan, dan fisik/ grafika. Standar yang berkaitan dengan materi dalam suatu buku, yaitu kelengakapan materi, materi yang memunculkan penalaran, pemecahan masalah, adanya komunikasi, adanya keterkaitan dengan materi lain, adanya kegiatan/tugas yang mendukung tujuan kompetensi yang dirumuskan dalam kurikulum, uraiannya tidak tumpang tindih, dan tersedia soal-soal yang kontekstual.

Pada PLPG yang dilaksanakan di UMS tahun 2009 ditemukan fakta bahwa para peserta PLPG, yaitu guru SMP kesulitan dalam memilih bahan ajar dan masih banyak yang mengandalkan buku teks yang bias jender. Hal ini disebabkan pemilihan bahan ajar memerlukan ketekunan dan kompetensi guru. Guru seharusnya tidak memilih buku pelajaran Bahasa Indonesia yang masih bias jender pada bacaan, pada latihan, dan pada gambar. Bias jender yang dilakukan dalam bahan ajar itu ada beberapa macam bentuk. Bentuk bias jender yang paling banyak ditemukan adalah adanya dominasi laki-laki terhadap perempuan.

Kondisi tersebut menunjukkan bahwa mencari dan menentukan bahan ajar responsif jender kepada siswa SMP membutuhkan kreativitas guru agar tujuan kegiatan belajar mengajar dapat tepat sasaran. Buku ajar sebaiknya tidak dijadikan kitab suci oleh guru karena akan membatasi kreativitas guru dalam menerapkan KTSP di sekolah, tetapi buku ajar hanya dijadikan sebagai pelengkap (suplemen) bagi guru untuk mengajar. Di luar permasalahan tersebut, sesungguhnya KTSP dalam 
pelajaran Bahasa Indonesia merupakan peluang untuk memperkenalkan wacana jender kepada siswa sejak dini. Oleh karena itu, sangat diperlukan kompetensi bagi guru untuk menyusun bahan ajar sehingga penting diadakan pelatihan penyusunan bahan ajar Bahasa Indonesia bagi guru SMP/MTs di Surakarta.

\section{Perumusan Masalah}

Berdasarkan uraian analisis situasi, rumusan masalah dalam artikel ilmiah ini adalah bagaimana pelatihan penyusunan bahan ajar Bahasa Indonesia berperspektif kesetaraan jender bagi guru SMP/MTs di Surakarta?

\section{Tinjauan Pustaka}

a. Ihwal Jender

Konsep penting yang perlu dipahami dalam rangka membahas masalah kaum perempuan adalah membedakan konsep seks dan konsep jender. Pemahaman dan pembedaan terhadap kedua konsep tersebut sangat diperlukan dalam melakukan analisis untuk memahami persoalan-persoalan ketidakadilan sosial yang menimpa kaum perempuan. Konsep seks (jenis kelamin) merupakan penafsiran atau pembagian dua jenis kelamin manusia yang ditentukan secara biologis yang melekat pada jenis kelamin tertentu, misalnya manusia jenis laki-laki memiliki jakala, memproduksi sperma, dan lain sebagainya. Sedangkan perempuan memiliki rahim, memproduksi sel telur, dan lain sebagainya. Adapun konsep jender merupakan suatu sifat yang melekat pada kaum laki-laki dan perempuan yang dikonstruksi secara sosial atau kultural. Misalnya, perempuan itu dikenal lemah lembut, emosional, dan keibuan. Sementara lakilaki dianggap kuat, rasional, jantan, dan perkasa. Ciri dari sifat itu sendiri merupakan sifat-sifat yang dapat dipertukarkan. Artinya, ada laki-laki yang lemah lembut, emosional, dan keibuan. Sementara itu, ada perempuan yang kuat, rasional, dan perkasa (Fakih, 2007: 7-8).

Menurut Kumala (2009) perbedaan jender adalah perbedaan kelamin yang diposisikan dalam kehidupan sosial. Feminis adalah kaum yang berjuang mengubah kedudukan kaum perempuan atau berbagai pemikiran tentang kaum perempuan. Dalam hal ini, sejak berabad-abad lalu posisi perempuan ditempatkan di bawah jender laki-laki, dianggap sebagai second sex (jenis kelamin kedua). Ada masa ketika seorang bayi perempuan lahir, bayi tersebut dibunuh. Ada pula masa, yang boleh melakukan voting pemilihan umum hanya laki-laki dan perempuan dianggap tidak punya hak suara. Kesetaraan jenderlah yang menjadi tuntutan utama kaum feminis. Sebetulnya, seorang feminis tidaklah harus perempuan. Akan tetapi, kata feminis selalu terpatri dalam benak banyak orang dengan sosok perempuan. Menurut Wiludjeng (2005: 7) stereotip perempuan dan laki-laki di mayarakat, menyebabkan terjadinya ketidakadilan jender. Stereotip berkaitan dengan pelabelan yang dapat menyebabkan kaum perempuan berada pada posisi dan kondisi tidak mengutungkan.

b. Bahan Ajar yang Responsif Jender

Pusat Kurikulum Depdiknas berdasarkan Undang Nomor 22 Tahun 1999, Peraturan Pemerintah Nomor 25 Tahun 2000 pasal 2 ayat 3 butir 11, dan Undang-undang Republik Indonesia Nomor 20 Tahun 2003 tentang Sistem Pendidikan Nasional, pasal 35 ayat 1 membuat proyek pedoman penyusunan bahan ajar berprespektif jender, yang diharapkan menjadi rambu-rambu para 
para penulis bahan ajar, sehingga dapat tercapai pembelajaran yang berprespektif jender.

Dalam Naskah Akademik Bahan Ajar Jender, antara lain dinyatakan bahwa pendidikan seharusnya memberikan kesempatan kepada semua pihak untuk memperoleh posisi yang sejajar, dengan mengacu pada usaha, kerja keras dan bukan atas dasar hak istimewa. Oleh karena itu, materi ajar yang dikemas dalam buku-buku pelajaran, begitu juga pelaksanaan belajar-mengajar di kelas harus berwawasan jender. Untuk dapat menghasilkan buku ajar yang berwawasan jender dan merancang serta melaksanakan belajar mengajar di kelas, para guru memerlukan suatu ramburambu yang dapat berfungsi sebagai pedoman baginya untuk menulis bahan ajar dan merancang kegiatan belajar mengajar yang berwawasan jender (Wiyatmi, 2008:7-8). Dengan demikian, diskriminasi jender yang selama ini terjadi di masyarakat dapat terhapus secara perlahan-lahan.

\section{c. Pemilihan Buku Teks}

Buku teks pelajaran Bahasa Indonesia membantu siswa dalam mencapai kompetensi yang harus dicapai pada mata pelajaran tersebut. Pada proses pemilihan buku teks untuk siswa, guru memiliki kebebasan penuh untuk menentukan buku dari penerbit mana yang paling tepat digunakan untuk siswanya. Pada kesempatan itu, guru memiliki peluang untuk memilih buku yang tidak bias jender. Pusat Perbukuan pada 2005 telah menyeleksi sejumlah buku dari berbagai penerbit yang akan digunakan untuk kegiatan belajar mengajar di sekolah (Irawan, 2008:13). Pada proses penyeleksian tersebut, salah satu butir yang disampaikan panitia adalah pengenalan wacana jender pada siswa. Panitia mengharapkan tidak ada lagi kalimat-kalimat yang bias jender, seperti pada pembahasan contoh kalimat di atas. Panitia mengharapkan sebuah buku teks yang mendukung kesetaraan jender.

\section{Tujuan dan Manfaat}

Kegiatan ini memiliki tiga tujuan, yaitu

a. Membuka wawasan guru dan pemerhati bahasa Indonesia mengenai kesetaraan jender dalam kehidupan sehari-hari.

b. Memberikan wawasan untuk menganalisis nilai ketidaksetaraan/ kesetaraan jender.

c. Menyusun bahan ajar Bahasa Indonesia berperspektif kesetaraan jender.

Adapun manfaatnya adalah

a. Turut mengusahakan adanya kesetaraan jender dalam kehidupan sehingga secara tidak langsung ikut meminimalisasi terjadinya kekerasan dan ketidakadilan yang terjadi pada laki-laki dan perempuan.

b. Memperkaya pendekatan pembelajaran Bahadsa Indonesia..

c. Menggairahkan kegiatan bersastra di kalangan guru, dan pemerhati bahasa Indonesia.

\section{METODE PELAKSANAAN}

\section{Khalayak Sasaran}

Kegiatan pelatihan penyusunan bahan ajar Bahasa Indonesia ini memiliki khalayak sasaran, yaitu guru Bahasa Indonesia SMP/MTs di Surakarta (30 orang). Akan tetapi, pada pelaksanaan pelatihan guru yang datang berjumlah 13 orang.

\section{Metode Kegiatan}

Kegiatan pengabdian masyarakat tentang "Pelatihan Penyusunan Bahan 
Ajar Bahasa Indonesia bagi Guru SMP/ MTs di Surakarta” dilakukan dengan beberapa tahapan.

a. Persiapan

Tahap persiapan merupakan tahap awal sebelum pelaksanaan pengabdian. Dalam tahap ini ada beberapa hal yang dilakukan.

1) Koordinasi internal, dilakukan oleh tim untuk merencanakan pelaksanaan secara konseptual dan operasional.

2) Koordinasi eksternal, dilakukan dengan pihak luar terkait, program studi.

3) Konfirmasi pemateri, menghubungi para pemateri terkait atas kesediaan menjadi pemateri dalam kegiatan ini.

4) Pembuatan instrumen pengabdian, seperti presensi.

5) Persiapan konsumsi, publikasi, lokasi, dokumentasi, dsb.

b. Pelaksanaan Pelatihan

Pelaksanaan kegiatan ini tanggal 1 Mei 2010 di Gedung C.4. Tahap ini merupakan tahap sosialisasi dilaksanakan, mencakup beberapa kegiatan.

1) Pembukaan Program Pengabdian Masyarakat

Program ini rencananya akan dibuka secara resmi oleh Ketua LPPM atau Ketua Prodi PBSID FKIP UMS. Pembukaan program ini dihadiri oleh pihak LPPM UMS, para pemateri merangkap pengabdi, pihak dari Prodi PBSID FKIP UMS, dan seluruh peserta. Peserta pelatihan ini berjumlah 13 orang dari guru Bahasa Indonesia di Surakarta.

2) Penyajian Materi

Materi mengenai penyusunan bahan ajar responsif jender.
3) Sesi tanya-jawab

Di akhir sesi akan diadakan sesi tanya-jawab atau dialog, baik antara peserta dengan pemateri maupun antara peserta dengan peserta.

\section{Rancangan Evaluasi}

Jenis evaluasi yang diterapkan dalam kegiatan ini mencakup evaluasi produk, evaluai proses, dan evaluasi kebermaknaan.

a. Evaluasi Produk

Evaluasi produk dilakukan berdasarkan tingkat keberhasilan produk yang dihasilkan para peserta selama kegiatan pengabdian berlangsung.

b. Evaluasi Proses

Proses kegiatan program ini akan dicermati untuk dilihat ketercapaian dan peningkatan proses. Hal ini dilihat dari respon peserta.

\section{HASIL DAN PEMBAHASAN}

1. Penyampaian Materi tentang Penyusunan Bahan Ajar Bahasa Indonesia Berperspektif Kesetaraan Jender

Penyampaian materi mengenai penyusunan bahan ajar berperspektif kesetaraan jender dilaksanakan selama 30 menit. Penyampaian materi dilengkapi dengan makalah dan slide power point. Hal ini untuk menunjang pemahaman peserta pelatihan terhadap isi pembicaraan. Adapun pemateri penyusunan bahan ajar Bahasa Indonesia berperspektif kesetaraan jender adalah Prof. Dr. Markhamah. Pemateri didampingi oleh seorang moderator, yaitu Miftakhul Huda.

Pada tahap penyampaian materi pemateri memaparkan beberapa hal, di antaranya pengertian bahan ajar, elemenelemen dalam bahan ajar, kajian jender, jender pada bahan ajar, dan mekanisme 
pengembangan bahan ajar Bahasa Indonesia Berperspektif Kesetaraan Jender.

a. Pengertian bahan Ajar

Bahan Ajar merupakan bahanbahan atau materi pelajaran yang disusun secara sistematis, yang digunakan guru dan siswa dalam proses pembelajaran. Bahan ajar sebagai media dan metode pembelajaran sangat besar artinya di dalam menambah dan meningkatkan efektivitas pembelajaran.

Bahan ajar memiliki sifat unik dan spesifik. Unik artinya bahan ajar tersebut hanya dapat digunakan untuk audiens tertentu dalam suatu proses pembelajaran tertentu. Spesifik artinya isi bahan ajar tersebut dirancang sedemikian rupa hanya untuk mencapaitujuan tertentu dari audiaens tertentu pula. Dengan demikian, pada bahan ajar terdapat pedoman untuk guru dan siswa, tujuan bahan ajar untuk siapa, serta terdapat prosedur dan cara pemanfaatannya. Sementara itu, tulisan atau buku yang bukan bahan ajar tidak dilengkapi pedoman untuk siswa dan guru, tujuan bahan ajar itu untuk siapa, tidak terdapat prosedur dan cara pemanfaatannya.

b. Elemen-elemen dalam Bahan Ajar Agar memenuhi fungsinya, bahan ajar/ modul yang ditulis hendaknya memenuhi elemen modul. Elemen yang dimaksud di anataranya adalah konsistensi, format, organisasi, daya tarik, ukuran huruf, dan spasi kosong. Konsistensi yang dituntut berkaitan dengan bentuk dan jenis huruf, jarak spasi, tata letak, dan pengetikan. Format terkait dengan penggunaan kolom dan ukuran kertas. Adapun organisasi mencakup tampilan peta/bagan, organisasi materi pem- belajaran, penempatan gambar/naskah/ilustrasi, dan organisasi antarbab.

Daya tarik berkaitan dengan cover, isi modul, dan tugas. Adapun bentuk dan ukuran huruf yang digunakan hendaknya yang mudah dibaca oleh siswa. Sedangkan spasi kosong dapat berfungsi untuk menambah catatan penting dan memberikan kesempatan/ jeda kepada siswa/ peserta diklat.

c. Kajian Jender

Jender adalah suatu istilah konsep yang tidak sama dengan seks atau jenis kelamin. Jender merupakan seperangkat peran yang diperuntukkan untuk laki-laki dan perempuan yang disosialisasikan melalui proses sosial budaya. Jender adalah atribut yang diletakkan, dikodifikasikan, dan dilembagakan secara sosial maupun kultutal kepada laki-laki dan perempuan.

Jender berbeda dengan seks. Seks atau jenis kelamin adalah pensifatan atau pembagian dua jenis kelamin manusia yang ditentukan secara biologis yang melekat pada jenis kelamin tertentu. Misalnya manusia laki-laki adalah manusia yang memiliki penis, memproduksi sperma, dan memiliki jakala. Perempuan adalah manusia yang memiliki alat reproduksi, seperti rahim, memproduksi telur, memiliki payudara, dan memiliki vagina.

d. Jender pada Bahan Ajar

Penelitian Markhamah tahun 2004 menemukan bias jender dalam Buku Pelajaran Bahasa dan Sastra Indonesia berupa dominasi laki-laki terhadap perempuan, subordinasi perempuan, stereotip, beban kerja lebih, dan marginalisasi perempuan. 
Selain itu, Muthaliin melakukan penelitian tahun 2001 khusus mengenai buku pelajaran menyatakan bahwa meteri pembelajaran, baik buku paket terbitan Depdiknas maupun buku-buku terbitan lain, mengandung banyak konsep bias jender. Bias itu termanifestasikan dalam rumusan dan gambar suasana, kegiatan, aktivitas, penggambaran, profesi, peran, permainan, pemilikan, tugas, dan tanggung jawab yang dimiliki atau dibebankan pada masing-masing jenis kelamin.

e. Mekanisme Pengembangan Bahan Ajar Bahasa Indonesia Berperspektif Kesetaraan Jender

Penyusunan modul merupakan proses penyusunan materi pembelajaran yang dikemas secara sistematis sehingga siap dipelajari oleh siswa untuk mencapai kompetensi atau subkompetensi. Ada lima langkah utama dalam mengembangkan bahan ajar, yaitu analisis, perancangan, pengembangan, evaluasi, dan revisi.

Penulis materi ajar Bahasa dan Sastra Indonesia yang ingin mengembangkan materi ajar berperspektif kesetaraan jender harus merancang tempat atau bagian yang akan dimasuki kesetaraan jender dan bahan yang mengandung perspektif jendernya itu. Ada beberapa cara menempatkan aspek-aspek kesetaraan jender. Tempat yang dimaksud di antaranya, bacaan, latihan, dan magian lain (: gambar).

Bacaan yang dipakai dapat disesuaikan dengan topiknya, missal puisi, artikel, cerpen, dan potongan naskah drama. Penulis sebaiknya memilih bacaan yang bisa menunjukkan kesetaraan jender. Artinya, jika artikel yang dipakai mengandung aspek kesetaraan jender dapat memberikan wawasan kesetaraan jender pula kepada siswa.

\section{Diskusi tentang Penyusunan Bahan Ajar Bahasa Indonesia Berperspektif Kesetaraan Jender}

Diskusi mengenai bahan ajar Bahasa Indonesia yang mengandung nilai kesetaraan jender dilakukan selama 45 menit setelah pemateri menyampaian materi bahan ajar Bahasa Indonesia berperspektif kesetaraan jender. Proses diskusi dipimpin oleh Miftakhul Huda. Dalam diskusi terdapat tiga orang peserta yang menyatakan ide, gagasan, dan beberapa pertanyaan.

a. Peserta pertama

Pembelajaran berperspektif kesetaraan jender memang perlu dipersiapkan dari segala aspek, di antaranya adalah bahan ajar. Akan tetapi, selain bahan ajar guru perlu mempersiapkan setting suasana pembelajaran yang menunjang kesetaraan jender. Perkembangan yang muncul di Inggris, ada sebuah usulan, bagaimana jika pembelajaran memisahkan antara laki-laki dan perempuan. Apakah itu akan memperkuat atau mempercepat tujuan pembelajaran yang berperspektif jender?

Berdasarkan pernyataan tersebut pemateri merespon bahwa usaha memisahkan kelas antara lakilaki dan perempuan malah akan memunculkan ketidaksetaraan jender dalam pembelajaran. Hal ini disebabkan tidak ada interaksi antara laki-laki dan perempuan. Dengan tidak adanya interaksi akan berdampak pada tertutupnya pandangan bahwa laki-laki dan perempuan memiliki 
kedudukan yang sama pada tataran sosial.

b. Peserta kedua

Buku-buku paket Pelajaran Bahasa dan Sastra Indonesia dulu memang banyak terjadi bias jender, misalnya bapak membaca koran, Andi bermain, dan ibu memasak. Hal ini secara tidak langsung membentuk mainstream anak bahwa yang namanya bapak itu kebiasaannya membaca, anak itu bermain, dan ibu memasak. Berdasarkan hal tersebut pada akhirnya terjadi tugas ganda pada diri ibu. Akan tetapi, saya melihat, dalam buku-buku ajar Bahasa Indonesia saat ini hal itu tidak lagi dominan, misalnya bapat dan ibu bersih-bersih rumah, Ani dan Budi menyapu halaman.

Berdasarkan hal tersebut pemateri merespon baik karena hal tersebut mengindikasikan bahwa guru, siswa, atau para ahli sudah melai memperhatikan aspek kesetaraan jender dalam membuat bahan ajar.

\section{c. Peserta ketiga}

Kesetaraan jender memandang kedudukan laki-laki dan perempuan pada status sosial yang sama, termasuk pekerjaan. Bagaimana dengan perempuan yang bekerja di tambang minyak misalnya?

Berdasarkan pertanyaan tersebut pemateri menjawab bahwa kesetaraan jender bukan berarti melihat perempuan sama persis dengan menafikkan kondisi fisik masing-masing. Jender berbeda dengan kodrat, kodrat bersifat fitrah illahiah, misalnya melahirkan dan menyusui. Akan tetapi, jender melihat pada aspek peran pada tataran sosial.
Dengan demikian, alas an penolakan seseorang bekerja di pengoboran minyak misalnya, bukan karena dia laki-laki atau perempuan tetapi karena alasan kemampuan.

\section{SIMPULAN DAN SARAN}

\section{Simpulan}

Pengabdian Masyarakat dalam bentuk pelatihan penyusunan bahan ajar Bahasa Indonesia berperspektif kesetaraan jender bagi guru SMP/MTs di Surakarta dilaksanakan melalui dua tahapan, yaitu ceramah oleh pemateri mengenai penyusunan bahan ajar Bahasa Indonesia yang mengandung nilai kesetaraan jender dan diskusi antara pembicara dengan peserta pelatihan mengenai kondisi konkret bahan ajar yang ada di sekolah. Pada tahap penyampaian materi pemateri memaparkan beberapa hal, di antaranya pengertian bahan ajar, elemenelemen dalam bahan ajar, kajian jender, jender pada bahan ajar, dan mekanisme pengembangan bahan ajar Bahasa Indonesia Berperspektif Kesetaraan Jender. Adapun pada tahap diskusi terdapat tiga peserta yang mengeksplor permasalahan untuk didiskusikan.

\section{Saran}

Berdasarkan pembahasan yang telah dipaparkan, dapat disarankan beberapa hal.

a. Penyusunan bahan ajar Bahasa Indonesia berperspektif kesetaraan jender perlu dilakukan dalam rangka membuka wawasan siswa mengenai posisi dan peran antara laki-laki dan perempuan sama.

b. Pelatihan-pelatihan mengenai penyusunan bahan ajar perlu lebih banyak dilakukan, terutama pelatihan yang aplikatif.

\section{PERSANTUNAN}

Pengabdian masyarakat ini terlaksana karena bantuan beberapa pihak. Oleh karena itu, kami mengucapkan terimakasih atas segala bantuan yang telah diberikan. 
1. LPPM UMS sebagai penyandang dana dan pemberi ijin pelaksanaan pengabdian masyarakat.

2. Prof. Dr. Markhamah yang ikut memberikan wawasan penyusunan bahan ajar Bahasa Indonesia.
3. Dra. Atiqa Sabardila, M. Hum. sebagai reviewer.

4. Bapak dan Ibu guru SMP di Surakarta.

\section{DAFTAR PUSTAKA}

Engineer, Asghar Ali. 2002. “Islam And Poligamy”. Musyawa: Jurnal Studi Jender dan Islam. Vol. 1 No. 1 Maret. Hal.27-39.

Fakih, Mansoer. 2007. Analisis Gender dan Tranformasi Sosial. Yogyakarta: Pustaka Pelajar.

Irawan, Ade HM., Meti Istimurti, dkk. "Peran Karya Sastra dalam Memperkenalkan Wacana Jender pada Siswa di Sekolah Dasar”. Konferensi Internasional Kesusastraan XIX / Hiski halaman 1 dari 16, Batu, 1214 Agustus 2008.

Kumala, Ratih. 2009. “Feminisme dalam Fiksi” .http://ratihkumala.com/blog/feminismedalam-fiksi-16.php. Diakses pada tanggal 28 Maret pukul 09.00 WIB.

Tilaar, H.A.R. 2004. Multikulturalisme, Tantangan Global dalam Transformasi Pendidikan Nasional. Jakarta: Grasindo.

Wiludjeng, Henny, dkk. 2005. Dampak Pembakuan Peran Gender terhadap Perempuan Kelas Bawah di Jakarta. Yogyakarta: LKiS.

Wiyatmi. “Menggagas Pembelajaran Sastra Berprespektif Gender” Konferensi Internasional Kesusastraan XIX / Hiski halaman 1 dari 15, Batu, 12-14 Agustus 2008. 